\title{
Green Gold is No More
}

\section{David Allens 2 T1}

University of Toronto

OISE Leadership, Higher and Adult Education

\section{A B S T R A C T}

With the collapse of the Banana industry, Gabriel Allahdua was thrust into a new reality that highlights the challenges of life under the externalities of neocolonialism. Almost 10 years later, Allahdua is one of many who have endured Canada's migrant worker programmes and is currently an advocate for change.

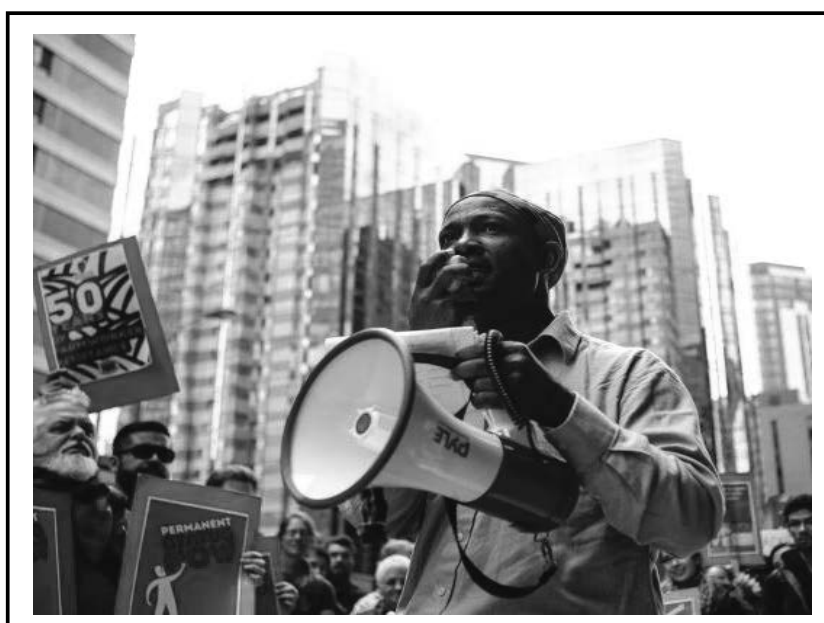

St. Lucian Activist and former migrant worker Gabriel Allahdua marches at a rally in support of migrant workers' rights in Ottawa in October 2016. (Justice for Migrant Workers)

Keywords: neocolonialism, St. Lucia, banana trade, migrant worker rights, trade liberalization, Canada

\section{$\mathrm{B} \mathrm{I} \mathrm{O}$}

David Allens has been an active member of the Caribbean Studies program and community since his first-year of undergrad at the University of Toronto when he served as Public Relations Coordinator for the Caribbean Studies Students' Union (CARSSU). As a MEd candidate in Adult Education and Community Development, David's current research interest surround the organizational development needs of public sector reform in the Common-Law Caribbean. 
Gabriel Allahdua sits in his mother's home on the eastern side of St. Lucia, where he grew up as the penultimate of her nine children. His mother and brother-in-law both recently passed, and Gabriel was on the island and in the homestead to "play [his] role." The two-story home on Austin Hill in Derniere Riviere was surrounded by freshly cut grass, and tropical shrubbery hiding in the shade of the housepossible case of re-infection. With this protective mechanism in mind, coupled with the Indigenous Caribbean inhabitants' immune systems, unaccustomed to alien diseases, viral and bacterial infection exploded into the leading cause of death of these once virile populations. As a result, disease ultimately posed a greater threat to survival than armed invasion (Montenegro and Stephens 2006, 1861).

"I was forced to become a migrant worker," the fifty-year-old said with a sardonic chuckle. "At that time, I was self-employed in five different things, I thought my income was diversified, and then the hurricane just destroyed my whole livelihood." Allahdua described Hurricane Thomas as the final "nail in the coffin" for many people on the island. The apex of a series of unfortunate - and in some instances orchestrated - events that led to the collapse of St. Lucia's largest industry.

Gabriel's father (who was 60 years old when his son was born) was a beekeeper. Having learned the trade "from a very tender age," Gabriel, the sixteenth of his father's seventeen known children, "continued the tradition after [his] father died in 1998." By the next year though,
"I had to diversify my income."

"I [started] operating a small greenhouse which, when compared to Canada and the United States of America (USA), it was like I was a hobbyist, but for me, in my tiny country it is something you can do to survive," or at least is a viable opportunity to supplement one's income.

What Gabriel did not know at the time was that "green gold" - the backbone of the countryside community of Dennery was on the verge of collapse. Nor would he have been aware of the devastating rippling effects its failure would lead to.

Since the 1950s, the United Kingdom (UK) allowed the protected sale of Caribbean bananas to replace unprofitable sugar production, and in 1975 under the Lomé Convention, this opportunity was expanded to the rest of the European Union, allowing African, Caribbean and Pacific countries to set prices for fixed amounts of commodities regardless of the global market price. These protections provided a way for the markets of former European colonies like St. Lucia to develop without relying on foreign aid.

At its peak in the early 1990s, the Lomé Convention protections ensured that the banana industry could increase to about 20 percent of the Windward Islands' GDP, providing immense opportunities for working-class St Lucians. 
"[Children] saw that their parents were not educated, and their parents could access credit. Their parents could buy a van, their parents could do some improvements on their own. That was a strong message to them that you do not need an education to survive." This was socialized in children from a young age. "The very first place where I worked, [ was La Ressource Primary School] in the countryside, and it has a record around the country for the lowest school attendance." "Once bananas start producing, you can harvest at least twice for the month," and on harvesting days, the children were taken away from school to work, Gabriel explained. The downside of this practice would soon be increasingly evident.

\section{Struggling against an 'unleashed' force}

Despite forming such a large share of the local GDP, Windward Island bananas only represented seven percent of European banana imports. Three-quarters came from US multinational corporations in control of the Latin American banana crop. These American multinationals petitioned to end the Lomé protections under Sec. 301 of the US Trade Act. As the European Commission put it in 1997, this "unleashed the full force of the US's legal and administrative resources, against the struggling democracies of 7 small Caribbean countries whose combined wealth [at the time was] less than $0.4 \%$ of that of the US." Throughout this process, few people in St. Lucia really considered that "green gold was no more." It was "not until it really hit us hard, that I would say they really took it seriously." "They always expected that the government would intervene," Gabriel continued. "People always expected green gold to be green gold." The World Trade Organization (WTO) twice ruled against the EU's banana import regime, and by April 2001, after a series of retaliatory sanctions were authorized by the WTO, the EU agreed to change its existing preferred zone framework by 2006 .

"We really experienced [the effects of those decisions] firsthand in St. Lucia because banana was our main crop," Gabriel said. Without those protections, St. Lucia's producers could not compete. "St. Lucia is a volcanic island and very mountainous," Gabriel explained. "Because it is mountainous, a lot of the banana cultivation [cannot be] mechanical." Large producers find it challenging to operate on the island without sufficient flatland suitable for industrial equipment, so instead, "a very large percentage of banana producers were small farmers" who grappled with high production costs. Gabriel paused, gathering his thoughts, before estimating that small farmers were responsible for over 60 to 75 percent of production. "At one point, it was estimated that we had between 12 and 15 thousand farmers. Multiply that 12 to 15 thousand by an average of three workers on harvesting days, and you have a very significant labour force working in agriculture."

"Can you imagine that at this point in time, we have less than 300 farmers? Can you imagine the impact?" Gabriel asked before repeating himself, reconsidering. "That's if we have 100 right now," he said, "that's the impact on employment." 
By 2012, this environment became untenable for both Gabriel and his five interconnected jobs. He had worked as both a beekeeper and a middleman for farmers while managing a convenience store and greenhouse. "All of that was happening in the countryside," Gabriel explained, where everything is easily susceptible to the exigencies of the global agriculture market.

"The WTO ruling[s] drove people off the land. That's one," he said, listing the factors that upended the livelihoods of those in Dennery. "Number two, the 2008 global financial crisis made things worse." And then, "imagine you don't have preferential treatment, your income is affected, and now you have to use a lot of that income to control a [disease] you never had before." Gabriel was referring to Black Sigatoka, "an important development" in the banana industry's decline. This amounted to fewer farmers able to support the convenience store or Gabriel's middleman operation. Next was the varroa mite - or "dynamite" as he called it - that ruined his beekeeping. "Anytime your hives are infested with [varroa mite], you lose anything between 50\% and $100 \%$, so that's a dynamite man." All that was left was the greenhouse, and "that could not sustain me," Gabriel said, shaking his head solemnly. Finally, "Hurricane Thomas in 2010 was the really hard straw that broke the camel's back for me and for most people."

So, "literally, I was forced [to migrate]. I didn't do that by chance, I didn't do that by choice." To Gabriel and others, these factors appear to amount to nothing less than a funnel that engineers environments in developing nations, forcing residents to migrate to the first world under less than ideal circumstances.

"So why do they interfere? Why do they exploit?" Gabriel asked rhetorically. "[America] has always seen the islands of the Caribbean to be in their backyard not only because of war [or] to protect their [domestic] interests and their own home but also, you know, America is grab; they just grab." "Capitalism is the very few at the expense of the majority, and that's what this is," he surmised. It demonstrates what first world countries may choose to ignore; their interference and exploitation wear away at the resiliency and safety nets of smaller countries - and their residents like Gabriel - leaving them susceptible to unavoidable factors like Hurricane Thomas and unexpected "dynamite."

Gabriel left his home very early on Thursday, January 12th, 2012, leaving enough time for the one-hour drive to George F.L. Charles Airport and the two hours needed to check-in and clear security before his 6:40 AM flight to Barbados.

Weeks before, an officer from the St. Lucian Ministry of Labour "had [Gabriel and the sixteen others travelling with him] sign a whole set of paperwork," never stopping to explain or give legal advice. "Just sign sign sign." At the airport, one of them was christened the government's armour bearer and received everyone's paperwork to be presented at Pearson International Airport. 
In hindsight, Gabriel sees his journey and these initial experiences as a harbinger for Canada's Seasonal Agricultural Worker Programme (SAWP).

The flight into Grantley Adams International Airport (BGI) left the soon to be 'temporary foreign workers' with an almost 10-hour layover on a "bright, sunny" $81^{\circ} \mathrm{F}$ day. During the layover, "I got to know that that same small airline had other flights into Barbados. So why couldn't they [book us one of those] you know?" he said, laughing. "What is the point, right? Why leave so early only to kill so many hours in Barbados." Two LIAT flights were scheduled to arrive at BGI before the eventually delayed AC967's original departure time.

BGI sports an open-air concept. Large dark blue fans with narrow blades cover the check-in area, while ceiling-high support columns surround a bar where Gabriel watched a replays of Windies cricket matches. "Can't recall the opponents, but it was exciting enough for me to watch over and over again."

The bar sits in the center of a courtyard that faces the curb and parking lot. Beyond both is Pug's - a red and white trimmed bar with picnic tables on its front veranda. While Gabriel watched the match, others in the group went to "socialize and get to know each other" and more importantly - to drink beers at a lower price within walking distance of the airport. Despite the annoyance of the layover, the experience would prove to be a reprieve.

\section{Under the cover of darkness}

As the nearly full 146-seater Airbus A320 taxied on the runway, Gabriel remembers feeling a sense of dissonance. Conflicted between "economics" and a growing ominous feeling.

To many, Canada is emblematic. "You cannot study geography and don't study Niagara Falls, you know? When you study about diversity, it's Canada. So, the way Canada is portrayed, I wanted to be there." Especially considering that when "in a difficult situation [...] you're anxious to better [it]." Conversely, workers' rights had begun to be diminished through coercion to comply with an onslaught of unexplained paperwork, lest they be labelled "a troublemaker."

Despite the red flags, Gabriel knew of no programme-related complaints. Moreover, he perceived acceptance into the SAWP to be the second time Canada had been influential at a "very important occasion in my life."

In 1989, Gabriel completed secondary school education, "thanks to the government and people of Canada." With a shortage of secondary institutions, many were unable to further their education. In the 1970s however, Castries Comprehensive was built as the first of 150 'Maple Leaf' schools and has continued to have Canadian governmental support. "It is because of Canada, I got a second chance to complete a secondary school education," so comforted by its image as "the gentleman," he trusted Canada again. Eager for "a great opportunity to get out of the vicious cycle of poverty." 
The Air Canada flight completed its descent into Pearson International Airport at 9:40 PM, arriving at the gate some six minutes later. Having never been outside of a tropical climate, Gabriel remembers the $5^{\circ} \mathrm{C}$ weather as the "height of winter."

"Just before I came up, I was in touch with a few friends in Canada. They asked me to dress warm. That's it, you know." At this point, "I don't know what on earth is 'dress warm'. In the Caribbean, once you wear a long sleeve, you're warm" he said, smiling.

After over an hour of processing, the seventeen workers were ushered onto a yellow school bus "only to find out that the bus did not have any heaters running." Leaving only worn vinyl seats and the cabin's exposed metal for warmth. Not knowing where they were headed or how long the journey would be, "we were all loud and full of comments, complaints and surprises. But it was a long day and a long ride," so as the bus made its way west onto Highway 401 off the 401 Express "we tried to get some sleep and keep ourselves warm."

Every so often, the driver would move onto the "sleep awakening portion" of the road as they drove through southern Ontario on Highways 8, 7 and 2 and "everyone instantly would burst the silence with a comment that the driver is sleepy."
Four hours later, the bus arrived at a farm just outside of a municipality of fewer than 28,000 people. By then, it was $-7^{\circ} \mathrm{C}$ and snowing. Attached to a 54-acre greenhouse was a packhouse which connected to one of two bunkhouses on the property. Donning his long sleeve, Gabriel entered. It was empty, its HVAC off - the ideal ending to a 3:00 AM greeter-less arrival. When rectified later that morning, they realized the correct bunkhouse was some 500m away. No one was around to tell them.

The second bunkhouse was detached from the larger structure and housed about sixty-two workers, including Kolocheto, who first arrived a few years earlier. Underequipped and with eight to each room - except for a converted nightwatchman room with six - things like cooking were "survival of the fittest." "According to the contract," these accommodations are free. In practice, this money is recouped through pay deductions for "support or some kind of strange name" Gabriel does not recall.

Kolocheto showed Gabriel his assigned room before going to his own to get a winter jackets. "He placed it at the bottom of the bunk bed, and he tells me that's your bed," Gabriel said, mirroring the moment by slapping his hand on the table. "To be honest, that was so powerful to me."

"I ended up spending four years in the program, and I ended up spending four years on that same bed that [Kolocheto] reserved for me," he said, shaking his head with a smile. 
Temporary foreign workers face numerous challenges, especially when isolated in rural communities where life revolves solely around the farm. Pay discrimination, inadequate health services, substandard housing, and pay deductions for benefits they have little or no access to plague the experience. Companies can request temporary foreign workers for roles when qualified Canadians or permanent residents are not available. However, requests are not made for positions with benefits like overtime and paid vacation. "The programme is designed that once you engage in primary agriculture, you do not get" anywhere near the benefits given to Canadian workers. There is a distinction made between Gabriel and those "on the same compound" doing Sunset ${ }^{\circledR}$ brand final packaging and distribution processes. One demarcated by physical separation.

"There are three qualities that Canada wants" in its temporary foreign workers. "People of colour, [those who] are illiterate, (or English is a second language), and/or [those who] are ignorant" to labour and human rights issues. During the three years Gabriel spent at Castries Comprehensive Secondary School, he studied the dark pages of history but was confident those histories remained in the past. Yet, "at the lowest point in my life," it became clear that the "dark pages that Canada helped me to study are alive and well in Canada."
Gabriel explained that this was not something he could let go by easily. "I rather see somebody with a smile on their face than somebody who is in fear," and Canada welcomes migrant workers into "a climate of fear." When combined with a Canadian "culture of silence," this keeps workers compliant. Living on the farm, "you do not see us; we are invisible," Gabriel said. "Our employer controls the travel agency that books our flight in and out of Canada. So, the moment you speak up, the farmer can send you back."

Gabriel has since become an advocate for those who remain in the programme.

"What is the recipe to exploit somebody? Ignorance and poverty," Allahdua said, answering his question. "The program keeps us poor by paying minimum wage," while immigration status yields barriers to essential services like education, keeping workers ignorant.

To Gabriel and others, it is clear that if the Canadian system had its way, temporary workers and the injustice hidden in the SAWPs policies, would be swept "under the cover of darkness." Out of sight and mind. Meanwhile western systems continue to stifle the region's ability to make and sustain its versions of "green gold" leading to a cyclical affect. Ultimately, the resiliency required to "resist these foreign powers comes with some element of education, some element of creativity and a desire for something better." 